\title{
LA JURISPRUDENCIA SOBRE APLICACIÓN DE LA INMUNIDAD DE JURISDICCIÓN EN MATERIA LABORAL
}

\author{
Miguel BRunaud Ramos* \\ Universidad de Chile
}

\section{INTRODUCCIÓN}

Las páginas siguientes tienen por objeto analizar la aplicabilidad de la inmunidad de jurisdicción, establecida en las Convenciones de Viena sobre Relaciones Diplomáticas y de Relaciones Consulares, en relación con causas laborales.

Se estudiará el concepto de inmunidad de jurisdicción, la teoría relativa o restringida de aplicación de la misma y el específico alcance de dicho concepto en materia laboral.

Analizaremos diversos fallos de nuestros tribunales superiores de justicia, con la finalidad de comparar la correcta aplicación de dicha institución en el ámbito laboral por parte de la Corte de Apelaciones de Santiago, en contraste con la errada doctrina sustentada por la Corte Suprema de Justicia.

Finalmente, abordaremos los recursos procesales con que cuentan las partes hoy día para impugnar las resoluciones judiciales dictadas con motivo de la aplicación de la inmunidad de jurisdicción, a partir de la supresión del recurso de casación.

\section{CONCEPTO DE INMUNIDAD DE JURISDICCIÓN}

La inmunidad de jurisdicción comprende el derecho de los Estados soberanos a no estar sometidos al ejercicio de poder de tribunales de otros Estados, lo que ha sido resumido en el principio par in parem non habet imperium.

La inmunidad de jurisdicción sustituye a la teoría de la extraterritorialidad, por corresponder a una teoría más racional y lógica, que permite eximir a los agentes diplomáticos de la jurisdicción local. Esta exención es una prerrogativa inherente a su representación, que como señala el autor Lucio Moreno Quintana, permite a los agentes diplomáticos prevalerse de una garantía excepcional o eximirse, en ciertos aspectos, de la observancia del orden jurídico común ${ }^{1}$.

A pesar de la sustitución del concepto de extraterritorialidad, llama profundamente la atención que nuestros tribunales superiores de justicia sigan sosteniendo que "tratándose de una embajada estamos en presencia de hechos que han acaecido en territorio extranjero"2.

\footnotetext{
Abogado, Máster en Derecho de los Negocios. Ilustrísimo Colegio de Abogados de Madrid y Universidad Francisco de Vitoria, España; Profesor de Derecho Económico, Facultad de Derecho de la Universidad de Chile. Contacto: mbrunaud@ brunaud.cl

1 Moreno QuinTAna, Lucio, Tratado de Derecho Internacional. Tomo I. Buenos Aires, 1963, p. 454.

2 Sentencia del Primer Juzgado de Letras del Trabajo, que acoge excepción de incompetencia por falta de jurisdicción RIT T-70-2010.
} 
El alcance de esta inmunidad de jurisdicción, es que el agente diplomático se halla exento de la jurisdicción penal del Estado donde se encuentra acreditado; así como también se encuentra exento de la jurisdicción civil.

Importa señalar que la exención de jurisdicción civil no es absoluta, ya que reconoce excepciones en materia laboral y previsional, tal como se señala expresamente en la Convención de Viena sobre Relaciones Diplomáticas, y en similares términos la Convención de Viena sobre Relaciones Consulares, como pasaremos a explicar.

Asimismo, la teoría moderna o relativa no acepta una inmunidad jurisdiccional absoluta para los Estados, sino que establece ciertas excepciones respecto de las cuales es posible entablar procesos válidos en contra de los Estados, distinguiendo entre los actos iure impe$r i$, que consisten en los actos de gobierno realizados por el Estado extranjero en calidad de soberano, que tendrían una inmunidad de jurisdicción de carácter absoluta, y los actos iure gestionis que no son estrictamente de aquella índole.

\section{INMUNIDAD DE JURISDICCIÓN EN MATERIAL LABORAL}

Tal como se adelantara, la exención de jurisdicción civil no es absoluta, ya que reconoce excepciones en materia laboral y previsional.

En efecto, tratándose del personal administrativo y técnico de una Embajada u Oficina Consular, no resulta aplicable la inmunidad de jurisdicción en beneficio de los agentes diplomáticos, en la medida que dichos trabajadores sean nacionales del Estado receptor o tengan residencia permanente en él.

Lo anterior, en virtud de lo dispuesto en el artículo 33 No 3 de la Convención de Viena sobre Relaciones Diplomáticas, que señala: "El agente diplomático que emplee a personas a quienes no se aplique la exención prevista en el párrafo 2 de este artículo, habrá de cumplir las obligaciones que las disposiciones sobre seguridad social del Estado receptor impongan a los empleadores".

El párrafo segundo de la norma antes citada hace referencia a la contratación de criados particulares, en cuyo caso el agente diplomático está exento de cumplir las normas de seguridad social vigentes en el Estado receptor, siempre que aquellos no sean nacionales del Estado receptor o no tengan en él residencia permanente, y se hallen protegidos por las disposiciones de seguridad social vigentes en el Estado acreditante o un tercer Estado.

Refuerza el cumplimiento que los agentes diplomáticos deben dar a las normas de seguridad social vigentes en el Estado receptor, lo dispuesto por el artículo 41 No 1 de la Convención de Viena sobre Relaciones Diplomáticas, que en lo pertinente expresa: "Sin perjuicio de sus privilegios e inmunidades, todas las personas que gocen de esos privilegios e inmunidades deberán respetar las leyes y reglamentos del Estado receptor”. En similares términos se reitera este principio en el artículo 55 No 1 de la Convención de Viena sobre Relaciones Consulares.

No es correcto sostener que las materias laborales o de seguridad social puedan estar incluidas dentro del vocablo "jurisdicción civil” que contiene el artículo 31 de la Convención de Viena. En primer lugar porque tal interpretación generaría una incongruencia den- 
tro de la propia Convención, habida cuenta que tendríamos por un lado el artículo 33 que ordena al agente diplomático cumplir con las disposiciones sobre seguridad social vigentes en el Estado receptor, mientras que el artículo 31 dejaría impune cualquier incumplimiento, amparando al agente diplomático con la inmunidad de jurisdicción. En segundo término, porque el artículo 31 distingue entre "jurisdicción civil" y "administrativa", a la hora de conferir la referida inmunidad, de tal modo que la expresión "jurisdicción civil” no puede ser interpretada en su sentido amplio, esto es, en general como referida a todos los asuntos no penales, sino en un sentido estricto, del mismo modo que en nuestro ordenamiento interno, conforme al artículo 45 del Código Orgánico de Tribunales, que distingue entre causas civiles y de comercio por un lado, y causas del trabajo, por el otro, a propósito de la competencia de los jueces de Letras en primera instancia. En igual sentido, la competencia que el artículo 50 del Código Orgánico de Tribunales entrega a un Ministro de Corte de Apelaciones para conocer en primera instancia de las causas civiles en que sean parte [...] los Embajadores [...] acreditados con el Gobierno de la República, al no incluir referencia alguna a las causas del trabajo, que, como vimos, el artículo 45 escinde de las causas civiles, permite concluir que en las causas laborales son aplicables las reglas de competencia ordinaria vigentes en Chile.

A pesar de lo claro que resultan las Convenciones de Viena sobre Relaciones Diplomáticas y sobre Relaciones Consulares, es posible advertir por parte de las Embajadas y Oficinas Consulares, situaciones de inobservancia de la legislación laboral y social vigentes en Chile, como casos de incumplimiento de las sentencias, en gran medida, derivadas de la errada interpretación y aplicación que la Excelentísima Corte Suprema ha dado a la inmunidad de jurisdicción en materia laboral.

Y repito que es una errada aplicación de nuestro Poder Judicial, por cuanto, el Poder Ejecutivo a través del Ministerio de Relaciones Exteriores ha sido claro y reiterativo, al momento de instruir a las embajadas y oficinas consulares que deben cumplir las normas laborales y de seguridad social vigentes en Chile.

El Ministerio de Relaciones Exteriores, a través de la Dirección General del Ceremonial y Protocolo, ha emitido diversas circulares dirigidas a las embajadas y oficinas consulares, señalándoles las situaciones detectadas de inobservancia de la legislación laboral y de seguridad, conjuntamente con invitarlas a cumplir lo dispuesto en las Convenciones de Viena que regulan la materia. Entre estas encontramos la Circular No 172 de 17 de mayo de 1999 y la Circular No 108 de 10 de abril de 2008.

En el mismo sentido, la Dirección del Trabajo ha emitido diversos dictámenes en los que a propósito de la contratación de personal administrativo, técnico o de servicio doméstico por las embajadas y oficinas consulares, que sean chilenos o residentes en el país, les recuerda que están obligadas a cumplir la legislación laboral, y que, a su respecto, estas asumen la calidad de empleadora y están obligadas a efectuar las cotizaciones previsionales correspondientes, de la misma forma que cualquier empleador nacional. Así por ejemplo, en el Dictamen Ordinario No 4539/213 de 05 de agosto de 1994 y Dictamen Ordinario No $3994 / 197$ de 2 de diciembre de 2002. 


\section{ANÁLISIS DE FALLOS}

Conforme a lo señalado precedentemente, según lo dispuesto en las Convenciones de Viena sobre Relaciones Diplomáticas y sobre Relaciones Consulares, tratándose de personal administrativo y técnico de una embajada u oficina consular, no resulta aplicable la inmunidad de jurisdicción en beneficio de los agentes diplomáticos, en la medida que dicho trabajadores sean nacionales del Estado receptor o tengan en él residencia permanente

Sin perjuicio de lo anterior, hemos de constatar con gran preocupación que nuestra Corte Suprema de Justicia aplica la inmunidad de jurisdicción en términos absolutos, haciéndola extensiva para el ámbito laboral, producto de una interpretación incorrecta de las normas que contemplan los tratados antes referidos.

Lo anterior, a diferencia de lo que resuelve la Corte de Apelaciones de Santiago, tribunal que hace un tiempo ha fallado, y de manera reiterada, que no corresponde aplicar la inmunidad de jurisdicción en materia laboral ${ }^{3}$.

Incluso la Corte de Apelaciones de Santiago ha permitido que se siga un proceso de ejecución en contra de una embajada, recogiendo los principios y jurisprudencia modernos del Derecho internacional ${ }^{4}$, tal como sucede en otros países ${ }^{5}$.

Con anterioridad a la reforma laboral que introdujo la Ley $\mathrm{N}^{\circ} 20.087$, la Corte Suprema conocía de la aplicación de la inmunidad de jurisdicción en materia laboral, a través de los recursos de casación que se interponían en contra de la sentencias de las Cortes de Apelaciones, que en general, aplicaban correctamente la teoría relativa de inmunidad de jurisdicción en materia laboral.

Con la modificación referida, la resolución que se pronuncia acogiendo una excepción de incompetencia, de carácter absoluto, fundado en la inmunidad de jurisdicción de que gozarían las embajadas y oficinas consulares, solo es susceptible de ser apelada, tal como lo consigna el artículo 453 No 1 del Código del Trabajo.

\footnotetext{
3 Véase en este sentido la resolución de fecha 15 de diciembre de 2009 dictada por la sexta sala de la Corte de Apelaciones de Santiago, en los autos Rol No 1059-2009, integrada por los ministros señores Jorge Zepeda Arancibia, Mario Rojas González y la abogada integrante señora Paola Herrera Fuenzalida. En el mismo sentido, véase la resolución de fecha 12 de agosto de 2010, dictada por la segunda sala de la Corte de Apelaciones de Santiago, en los autos Rol No 660-2010, integrada por los ministros señores Alfredo Pfeiffer Richter, Mario Rojas González y el abogado integrante señor Rodrigo Asenjo Zegers. El voto de minoría del ministro Pfeiffer.

4 Véase la resolución de fecha 31 de enero de 2011, dictada por la décima sala de la Corte de Apelaciones de Santiago, en los autos Rol Nº 69-2010, integrada por los ministros señores Carlos Cerda Fernández, la fiscal Sra. María Loreto Gutiérrez Alvear y la abogada integrante señora Regina Clark Medina.

5 El diario español "El País" publicaba el 7 de marzo de 2011 la siguiente noticia: El titular del Juzgado de lo Social número 10 de Madrid ha embargado las cuentas de la Embajada de Chile en las entidades Caja Madrid y Banco Santander de la capital de España por un importe superior a los 100.000 euros. El embargo es consecuencia de la sentencia dictada en enero de 2004 por el Tribunal Superior de Justicia de Madrid, por la que se declaraba improcedente el despido de un empleado de la representación diplomática de Chile en España, a la que se condenaba a readmitirlo en su puesto o a indemnizarle con más de 130.000 euros. A pesar de que la Embajada optó por la indemnización, nunca llegó a abonarla, según el auto judicial. Cuando la juez inició el procedimiento de embargo, la Embajada, con el apoyo de la Abogacía del Estado, alegó que las cuentas de la representación diplomática están protegidas por el Convenio de Viena y no pueden ser embargadas. La juez rechazó esta pretensión alegando que la Embajada nunca cuestionó la competencia del juzgado y que la inmunidad solo protege los bienes que están vinculados a la representación diplomática, pero no los de mera gestión ordinaria.

Fuente://www.elpais.com/articulo/espana/Embargadas/cuentas/Embajada/Chile/elpepiesp/20110307elpepinac_4/Tes
} 
La resolución que pronuncia la Corte de Apelaciones, si rechaza la aplicación de la inmunidad de jurisdicción en materia laboral, no es susceptible de recurso jurisdiccional, y de allí que se haya generado la práctica de interponer un recurso de queja para obtener un pronunciamiento por parte de Corte Suprema.

De conformidad al artículo 545 del Código Orgánico de Tribunales, el recurso de queja "...solo procederá cuando la falta o abuso se cometa en sentencia interlocutoria que ponga fin al juicio o haga imposible su continuación o definitiva...". Si consideramos la naturaleza de la resolución recurrida, dicho recurso solo procedería en el caso en comento, cuando se acoja la excepción de incompetencia, toda vez, que haría imposible su continuación.

Considerando lo anterior, es que en aquellos casos en que se dedujo recurso de queja, no siendo procedente su interposición en virtud de la naturaleza de la resolución recurrida, la Corte Suprema ha procedido a rechazarlos, pero actuando de oficio, en virtud de las facultades que confiere el artículo 84 del Código de Procedimiento Civil, ha entrado a anular lo resuelto por una Corte de Apelaciones, y ha acogido la inmunidad de jurisdicción en materia laboral, logrando de esta forma mantener inalterable el errado criterio con que aplica dicha institución ${ }^{6}$.

Hemos de concluir a esta altura del análisis, que si ya era grave que a través de los recursos jurisdiccionales la Corte Suprema estuviera aplicando el clásico concepto de inmunidad de jurisdicción en materia laboral, en desmedro de los derechos y garantías constitucionales de los trabajadores chilenos, el hecho que utilice una facultad de oficio lo hace aún más grave, ya que no está corrigiendo vicios procesales en la tramitación de las causas, sino que derechamente entra a decidir sobre el fondo del asunto.

Aún más grave resulta ser hoy día la errada interpretación, lo que resuelve la Corte Suprema, si consideramos que hoy vía Denuncia de Tutela los trabajadores chilenos pueden denunciar vulneraciones que afecten sus derechos fundamentales, según lo dispone el artículo 485 del Código del Trabajo, beneficio cautelar del cual estarían impedidos de ejercer los trabajadores chilenos que tengan como empleador una Embajada u Oficina Consular.

Es de esperar que nuestro máximo tribunal rectifique la doctrina que sustenta, y rechace la aplicación de la inmunidad de jurisdicción en materia laboral, tal como correctamente lo sostienen algunos integrantes de dicho tribunal, como los ministros Sres. Hugo Dolmestch Urra y Haroldo Brito Cruz, quienes a propósito del conocimiento de un recurso de queja, en un fallo de minoría sostuvieron:

“...los jueces recurridos incurrieron en grave falta o abuso al confirmar la decisión de primera instancia que acogió la excepción de falta de jurisdicción opuesta por el Estado extranjero en materia laboral, desde que, en la especie tienen aplicación las normas de los artículos $41 \mathrm{~N}^{\circ} 1$ y $33 \mathrm{~N}^{\circ} 3$ de la Convención de Viena sobre Relaciones Diplomáticas y 43 de la Convención de Viena sobre Relaciones Consulares, que dispo-

6 Véase la resolución de fecha 19 de octubre de 2010, dictada por la cuarta sala de la Corte Suprema, en los autos Rol No 6.116-2010, integrada por los ministros señores Patricio Valdés A., señoras Rosa María Maggi D., Rosa Egnem S. y los abogados integrantes señor Ricardo Peralta V. y señora Maricruz Gómez de la Torre V. También sentencia de catorce de septiembre de dos mil diez Rol N³ 3493-2010. 
nen que todas las personas que gocen de privilegios e inmunidades deben respetar las leyes y reglamentos del Estado receptor, en especial, deben cumplir las obligaciones que las disposiciones sobre seguridad social imponen a los empleadores, cuyo es, precisamente, el caso de autos"7.

\section{CONCLUSIÓN}

En mérito del análisis de las normas pertinentes contenidas en las Convenciones de Viena sobre Relaciones Diplomáticas y sobre Relaciones Consulares, es posible concluir de manera inequívoca, que el personal administrativo, técnico o de servicio de nacionalidad chilena que trabaja en una embajada o consulado, se encuentra sujeto en materia laboral y previsional a la legislación de Chile.

Por lo anterior, desde el establecimiento hasta el término de la relación laboral no procede aplicar las leyes del Estado acreditante.

Una interpretación opuesta de las normas aplicables y analizadas precedentemente, significaría aceptar el injusto resultado de obligar al trabajador chileno a una ilusa ocurrencia ante la jurisdicción del Estado extranjero o a requerir el auxilio diplomático chileno por vías letradas generalmente onerosas y extrajudiciales, atentando gravemente en contra de su derecho humano a la jurisdicción, peligro que el Derecho internacional actual tiende a prevenir y no a fomentar como lo hacen los actuales fallos de la Corte Suprema.

Por lo tanto, una correcta aplicación de la institución de inmunidad de jurisdicción en materia laboral, significa que los agentes diplomáticos o consulares estarán impedidos de invocar la inmunidad de jurisdicción en los casos laborales, debiendo someterse a los tribunales chilenos.

Que finalmente el fallo dictado válidamente por nuestros tribunales sea ejecutable, será materia de otro trabajo, cuando analicemos la aplicación de otra institución del Derecho internacional como es la inmunidad de ejecución.

\footnotetext{
Véase la resolución de fecha 9 de junio de 2011, dictada por la cuarta sala de la Corte Suprema, en los autos Rol No 739 2011, integrada por los ministros señores Milton Juica A., Hugo Dolmestch U., Haroldo Brito C., Guillermo Silva G. y el abogado integrante señor Nelson Pozo S.
} 